\title{
Effects of Growing Conditions of Marigold in Ilam District, Nepal
}

\author{
Bikash Khanal \\ Faculty, Department of Horticulture and Floriculture Management, Mahendra Ratna Multiple Campus, \\ Institute of Science and Technology, Tribhuvan University, Nepal \\ Email: bikaskhanal@gmail.com
}

Received 2 September 2014; revised 8 October 2014; accepted 2 November 2014

Academic Editor: Kalyani Mishra Tripathi, Department of Horticulture, Agriculture and Forestry University, Chitwan, Nepal

Copyright (C) 2014 by author and Scientific Research Publishing Inc.

This work is licensed under the Creative Commons Attribution International License (CC BY). http://creativecommons.org/licenses/by/4.0/

(c) (i) Open Access

\begin{abstract}
Different growing conditions with temperature and sunlight variation could vary in flower growth and quality of marigold. Plant growth and flowering characteristics are compared in three different conditions viz. plastic house, shade house and open field. Three varieties of marigold viz. Marvel Yellow, Marvel Orange and Marvel Garland with similar cultural practices were grown and observed. Each variety with 6 replications was grown in three different growing conditions. Plant height, leaves formation, length of leaves, number of days to flower, number of flowers per plant and post harvest analysis were recorded. Plant growth characteristics followed by flowering behavior were found significantly better in plants grown under plastic house. During post harvest experiment Marvel Garland variety grown under plastic house with wet post harvest treatment was found significantly better compared to other conditions.
\end{abstract}

\section{Keywords}

Marigold, Plastic House, Shade House, Open Field, Ilam, Plant Growth, Leaf Length, Flowering Time, Dry and Wet Post Harvest

\section{Introduction}

Different growing conditions result in varied climatic attributes in flower cultivation. The growing conditions followed by the commercial flower producers depend upon various factors including temperature and daylight. Flower development of many ornamental annual flowering plants is harmonized according to the season by us- 
ing changes in day and night length, which indicates that the flowering response is related to photoperiodic response to these plants [1]. Temperature also has a significant role in plant's development which linearly increases from its base temperature to the optimum [2]. Change in pattern of rainfall in hilly regions of Nepal is also the main reason of changing in flowering, fruiting and harvesting time of major flowers. Different types of plant species which will affect agricultural crops are shifting from lower altitudes to higher altitudes [3]. Growing of flowers in this cool climate is much better if growing condition could be managed better to maintain temperature and moisture. The vegetative as well as generative or productive phases of the crops have positive effect in the crops grown under the plastic tunnel compared to the open field [4].

In some flowers increase in day temperature has also resulted in decrease in the quality of flower [5]. Moreover with increased growing day temperature higher leaf area along with earlier rate of flowering was observed in some earlier research [6]. Reduction of daylight duration is also found to increase the flowering days of some species of ornamental plants [7]. Higher temperature and daylight up to optimum level favor in the process of photosynthesis. Only $8 \%$ to $10 \%$ of the energy in sunlight is converted to assimilate in the form of reduced sugars [8]. Increase in photosynthesis optimizes the process of plant growth and development [9].

Marigold is one of the most important flowers in the context of Nepal. It has religious as well as cultural importance. This flower is packed with the leaves of fern and mango leaves to welcome the people in different ceremonies as well as to offer the flowers to the god in different offerings [10]. Ilam is one of the subtropical and hilly regions of Nepal with a huge amount of rainfall during the months from June to September. Marigolds are the flowers which could be grown in a wide variety of soils. Marigold requires mild climate for luxuriant growth and profuse flowering. During severe winter including frost plants and flowers are killed and blackened. Generally marigold flowers are grown almost throughout the year but the main usable time of this flower is Tihar festival [11]. The local varieties of Ilam could not produce the quality flowers as in market demand, so Floriculture Association Nepal (FAN) wants to find out the production and quality criteria for other varieties in context of Ilam. So to promote the growth of the marigold cultivation and production in Ilam, this research is conducted to find out the growing condition of marigold varieties which are commercially grown in Nepal.

\section{Methodology}

The research was conducted in Department of Horticulture and Floriculture Management, Mahendra Ratna Multiple Campus, Ilam. The experiment was conducted from July to November 2013. Seeds of the three varieties of marigold (viz. Marvel Yellow, Marvel Orange and Marvel Garland) were sown in the solarized (the bed were covered with plastic for 21 days for solarization) nursery bed. Nursery bed of size $3 \times 1 \mathrm{~cm}$ and $15 \mathrm{~cm}$ raised beds is prepared by adding $10 \mathrm{~kg}$ FYM per meter square. The seeds were sown in line by line with row to row spacing of $10 \mathrm{~cm}$. Then the nursery bed was covered with semi open plastic tunnel. Watering was done in each day until plant germinates. After germination watering was done thrice a week.

After four weeks, the seedlings were transferred in three different growing conditions (viz. shade house, semiopen plastic house and open field). Shade house was a place which was covered with thatch and partial sunlight ( 5 - 6 hours) will enter in the house in the sunny day. Semi-open plastic house was the house covered with white plastic in the top and sides of the plastic house were partially open (with $15 \mathrm{~cm}$ all sides in the bottom for the purpose of aeration). In each growing condition there were 6 replications of marigold plants of three different varieties. The manuring of soil was done by nitrogen:phosphorus:potash in the ratio of 2:1:1 and $15 \mathrm{~kg}$ of compost manure $/ \mathrm{m}^{2}$. The spacing of plant in different growing conditions was $30 \times 30 \mathrm{~cm}$. Watering was done thrice a week and weeding was also conducted once a week.

The data recording was done after one week of transplanting of the seedlings from nursery to the different growing conditions. One extra row of plant of each variety of plants was planted as boarder plant and also between different varieties to prevent the varietal and human interactions. Increment in plant height was recorded in weekly interval until the formation of flower bud with the measuring scale. Previous week data is subtracted from the recorded week and height increment data was recorded and the data were filled in the tabulated format. In case of the longest leaf measurement, 2 to 3 longest leaves were measured every week to identify the longest one and the value is recorded in the tabulated form which was also conducted until the formation of flower bud. In case of recording the number of leaves formation in the plant, the leaves which were fully open and except the germinating leaves were counted every week. Previous week data was subtracted from the recorded week and number of leaves formation data was recorded and the data were filled in the tabulated format. The data 
were also recorded until the plant formed the flower bud. In case of number of days to flower the days were recorded after the appearance of the fully open flower (the outward petals fully turn outward and downward). Then the plants were kept for four weeks in the field. Only the fully open flowers were recorded as the number of flowers in the plant until the time frame of four weeks.

Post harvest experiment was conducted in the horticulture laboratory of the department of horticulture and floriculture management. Fully open three flowers from each plant were harvested for the purpose of post harvest experiment. Among each growing conditions 18 flowers were taken from which 9 flowers were selected for dry experiment with random selection. In this dry experiment the flowers were kept over the dry plastic and kept in spacing of $8 \times 8 \mathrm{~cm}$. In case of wet experiment also the same procedure was followed but the flowers were sprayed with distilled water every day in the evening time (5 - $6 \mathrm{pm})$. The days of post harvest life were recorded by observing the dehiscence and damage of the outermost petals of the flowers.

\section{Data Analysis}

The collected data were entered in excel program. Then the collected data were set in software named Minitab. Minitab (version 16) was used to conduct analysis of variance (GLM procedure). Comparisons of means have been performed with Tukey's pair wise comparison test at $\mathrm{p} \leq 0.05$. For graphical presentation sigma plot was used.

\section{Results and Discussion}

The increment in plant height per week was significantly higher $(\mathrm{p} \leq 0.05)$ in the plants growing inside the plastic house compared to the plants grown in shade house and open field (Figure 1). Number of leaves formation per week was found significantly $(\mathrm{p} \leq 0.05)$ higher in plants grown in plastic house and shade house compared to the open field in case of Marvel Yellow and Marvel Orange. But in case of Marvel Garland number of leaves formation per week is significantly higher $(\mathrm{p} \leq 0.05)$ in plastic house compared to other growing conditions (Figure 2). Higher temperature might have positive impact in case of Marvel Garland in leaves formation process. Length of the longest leaf was found to be significantly higher $(\mathrm{p} \leq 0.05)$ in shade house compared to other two growing conditions (Figure 3). In this context lower light might have the positive impact in elongation of the leaves in the plants. Plastic house and open field plants flower were flowering significantly $(p \leq 0.05)$ earlier compared to the plants grown under shade house in all the three varieties under study (Figure 4). The number of flowers per plant was found significantly higher $(\mathrm{p} \leq 0.05)$ in the plants growing inside the plastic house compared to the plants grown in shade house and open field (Figure 5).

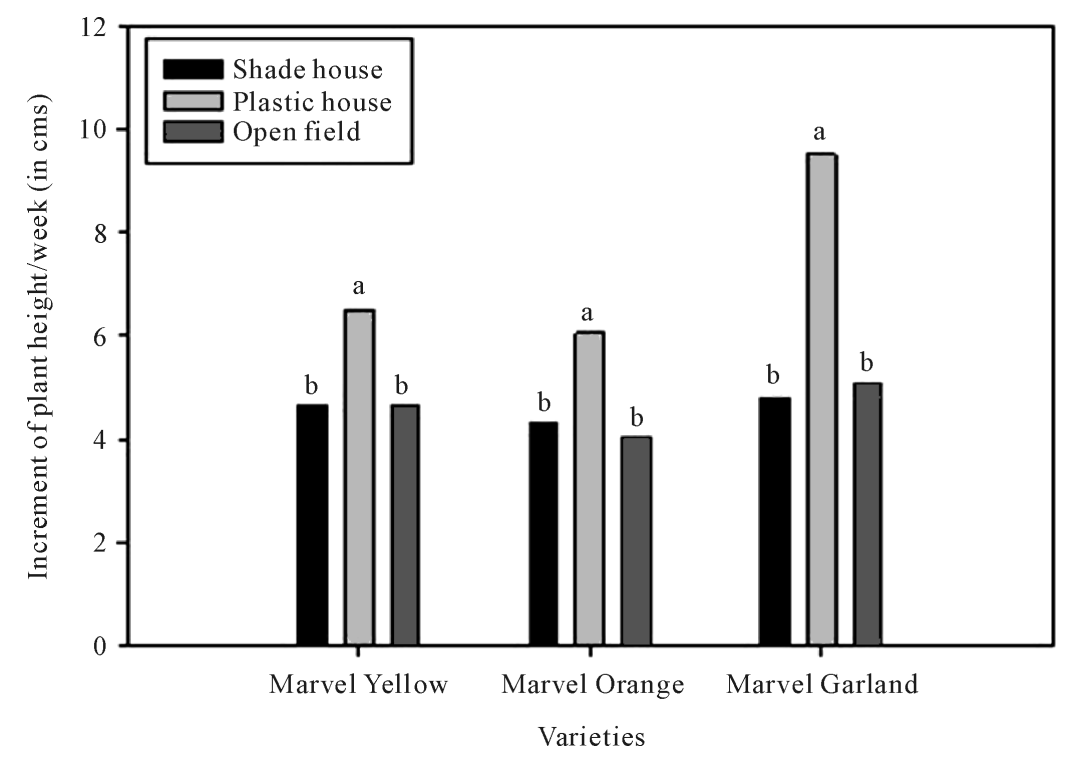

Figure 1. Effect of growing conditions in increment of plant height/week (in cms) in different varieties of marigold, text represents the significant difference values. 


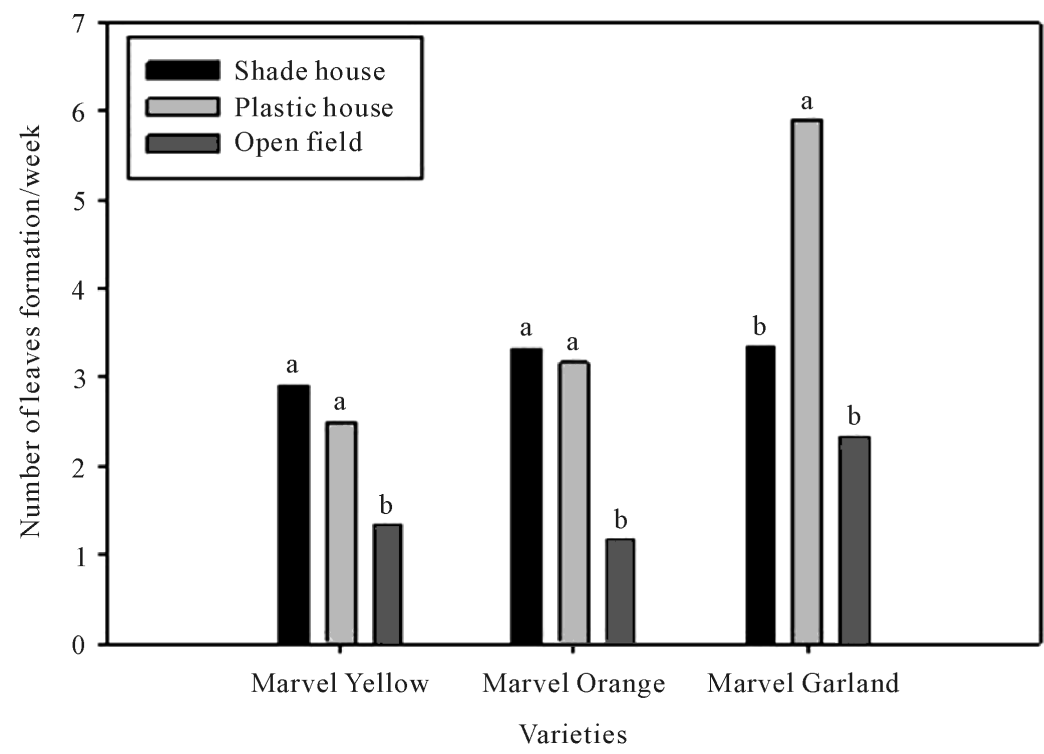

Figure 2. Effect of growing conditions in number of leaves formation per week in different varieties of marigold, text represents the significant difference values.

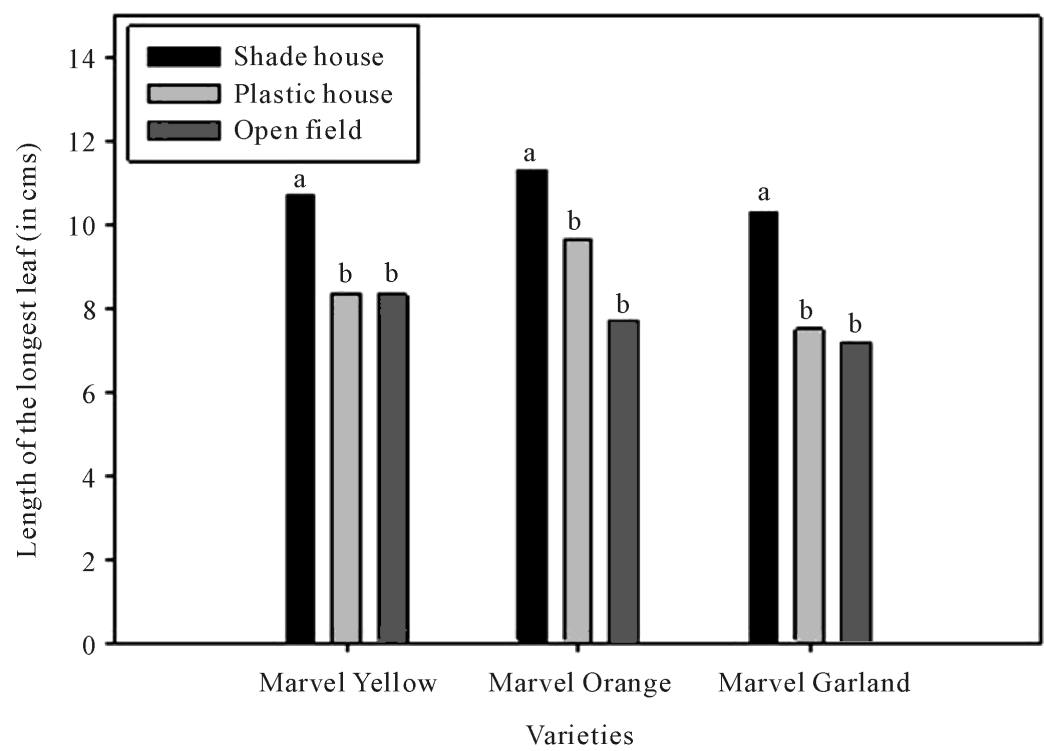

Figure 3. Effect of growing conditions in length of the longest leaf (in $\mathrm{cms}$ ) in different varieties of marigold, text represents the significant difference values.

Increased temperature up to optimum level along with photosynthetic light inside plastic house might be the reason of higher increment of plant height and flower number along with earlier flowering time [12] [13]. Optimum temperature and light required by flowering plants in plastic house might have resulted in decrease in number of leaves and leaf length. This shows that it might be the result of dry matter partitioning in generative phase of plant rather than vegetative phase [14]. Increasing temperature promoted plant height and flowering in the species in the present study. This is in accordance with previous results in studies with ornamental annual plants [15]. Some earlier research also revealed that with the higher growing temperatures marigold plants flower earlier compared to lower temperature growing conditions [16]. This result could also be explained by the reason that plant growth is comparatively slower in lower temperature condition than in higher growing temperature conditions due to lower carbon use efficiency which is shown in earlier research [17]. In open field there might be only ample light but in case of plastic house there is ample light along with higher temperature. 


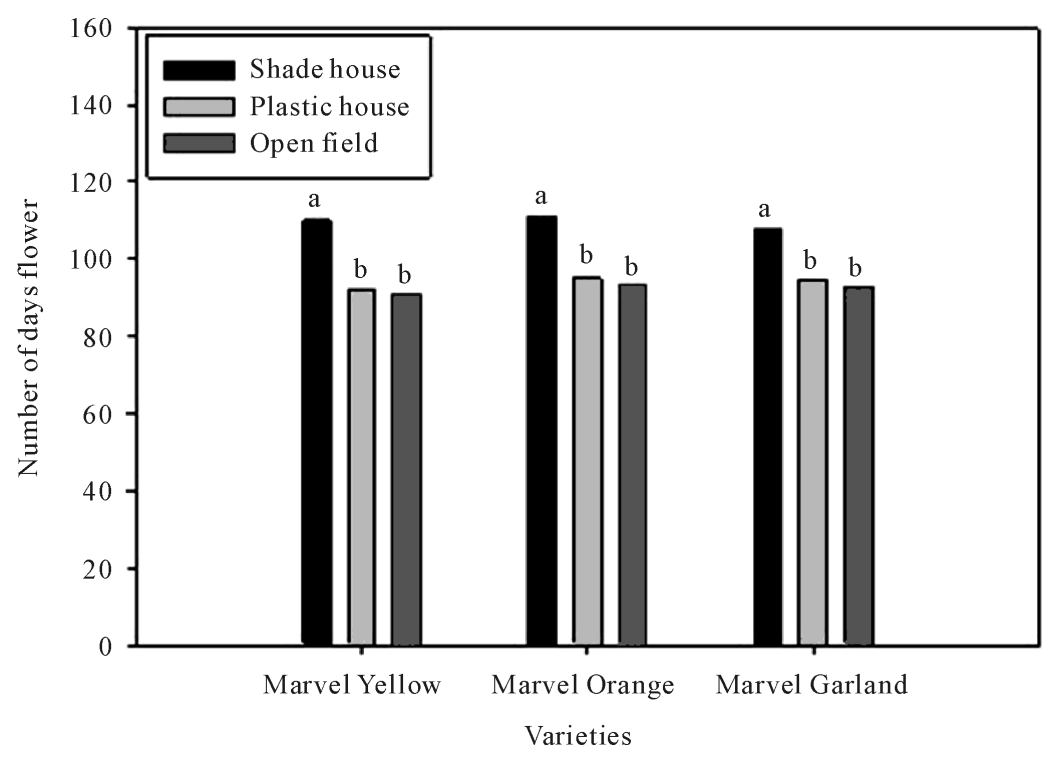

Figure 4. Effect of growing conditions in number of days to flower in different varieties of marigold, text represents the significant difference values.

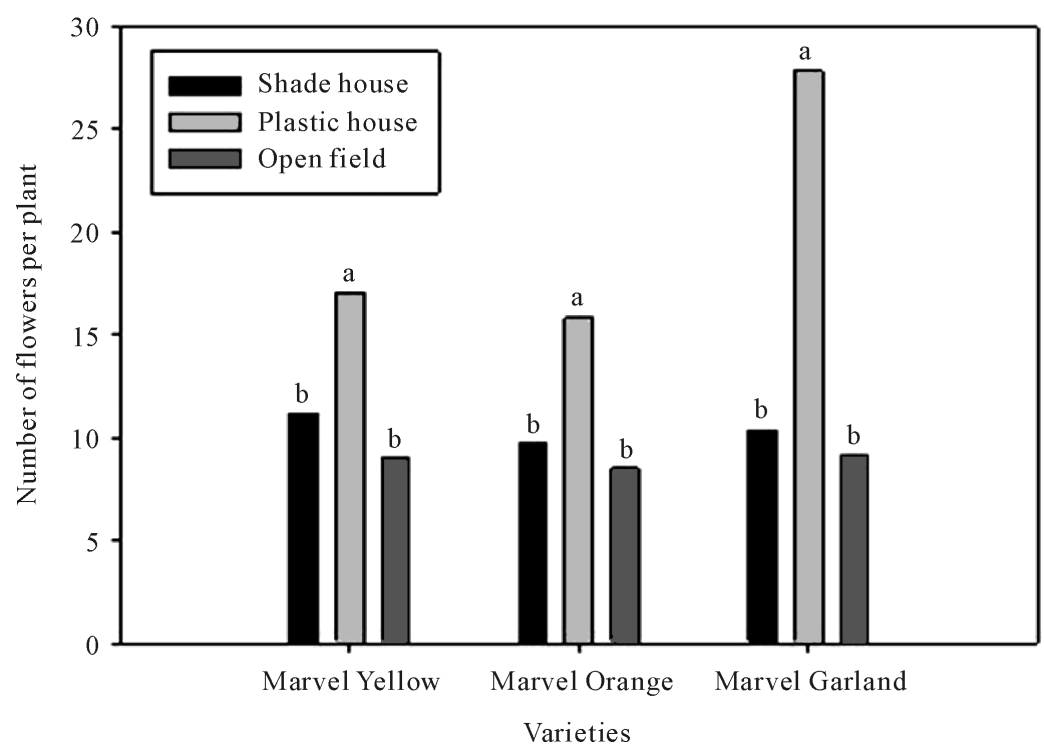

Figure 5. Effect of growing conditions in number of flowers per plant in different varieties of marigold, text represents the significant difference values.

So, with the higher temperature and light photosynthetic activities increases with the production of food materials in ample amount this results in better growth of plant. This also shows that during this time period of year optimum temperature could be obtained only under plastic house rather than shade house or open field.

Post harvest life was found to be significantly higher in the flowers grown under plastic house compared to shade house and open field. Comparison of varieties shows that Marvel Garland has significantly higher days of post harvest life than Marvel Yellow and Marvel Orange. In case of dry and wet experiment, wet storage conditions flowers sample have significantly longer days of post harvest life compared to dry storage conditions (Table 1). Higher temperature and light might be favorable for photosynthesis resulting in formation of higher amount of starch granule. This might be the reason of higher days of post harvest life inside plastic house compared to other growing conditions which is in support of earlier research conducted in petunia plant which shows lower vase life in flowers grown at lower temperature [18]. Different genetic factors are the results of longer 
Table 1. The results showing mean values of post harvest life along with significance level; text represents the significant difference values.

\begin{tabular}{ccc}
\hline Treatments & Post harvest life \\
\hline \multirow{2}{*}{ Growing conditions } & Shade house & $4.30 \pm 0.32 \mathrm{~b}$ \\
& Plastic house & $6.44 \pm 0.45 \mathrm{a}$ \\
Varieties & Open field & $4.63 \pm 0.35 \mathrm{~b}$ \\
& Marvel Yellow & $4.36 \pm 0.25 \mathrm{~b}$ \\
Storage conditions & Marvel Orange & $4.13 \pm 0.33 \mathrm{~b}$ \\
& Marvel Garland & $6.90 \pm 0.36 \mathrm{a}$ \\
& Wet & $6.64 \pm 0.41 \mathrm{a}$ \\
& Dry & $4.64 \pm 0.36 \mathrm{~b}$ \\
\hline
\end{tabular}

post harvest life of Marvel Garland compared to other two varieties. Maintenance of cell turgidity and higher water absorbance in case of wet conditions might be the reason of longer post harvest life in wet experiment compared to dry experiment which is similar to the earlier research conducted [19] which shows that wet storage of Narcissus flowers have improved post harvest life including maintenance of membrane integrity and soluble proteins followed by reduction in alpha amino acids.

\section{Conclusion}

It could be concluded that plants growing under lower light and lower temperature condition reduce the growth as well as flowering characteristics of marigold. The overall conclusion was that Marvel Garland variety grown under plastic house grows better followed by wet post harvest treatments in context of Ilam district, Nepal.

\section{Acknowledgements}

This project was financed by the Research Unit of MRMC, TU. I would like to thank Punya Prasad Bhattarai for proof reading of article and would like to thank Kushma Ghimire, Bishal Adhikari, Chadani Chaudhary, Kanchi Maya Waiba and Umesh Dhakal for their technical assistance.

\section{References}

[1] Garner, W.W. and Allard, H.A. (1920) Effect of the Relative Length of Day and Night and Other Factors of the Environment on Growth and Reproduction in Plants. Journal of Agricultural Research, 18, 553-606.

[2] Roberts, E. and Summerfield, R. (1987) Measurement and Prediction of Flowering in Annual Crops. In: Atherton, J.G., Ed., Manipulation of Flowering, Butterworths, London, 17-50.

[3] Schroeder, R.F. (1985) Himalayan Subsistence Systems: Indigenous Agriculture in Rural Nepal. Mountain Research and Development, 5, 31-44. http://dx.doi.org/10.2307/3673221

[4] Latimer, J.G. (1991) Container Size and Shape Influence Growth and Landscape Performance of Marigold Seedlings. HortScience, 26, 124-126.

[5] Moe, R. (1990) Effect of Day and Night Temperature Alternations and of Plant Growth Regulators on Stem Elongation and Flowering of the Long-Day Plant Campanula isophylla Moretti. Scientia Horticulturae, 43, 291-305. http://dx.doi.org/10.1016/0304-4238(90)90100-S

[6] Park, B.H., Oliveira, N. and Pearson, S. (1998) Temperature Affects Growth and Flowering of the Balloon Flower [Platycodon grandiflorus (Jacq.) A. DC. cv. Astra Blue]. HortScience, 33, 233-236.

[7] Holcomb, E.J. and Berghage, R. (2001) Photoperiod, Chilling, and Light Quality during Daylight Extension Affect Growth and Flowering of Tissue-Cultured Easter Lily Plants. HortScience, 36, 53-55.

[8] Zhu, X.-G., Long, S.P. and Ort, D.R. (2010) Improving Photosynthetic Efficiency for Greater Yield. Annual Review of Plant Biology, 61, 235-261. http://dx.doi.org/10.1146/annurev-arplant-042809-112206

[9] Kirschbaum, M.U. (2011) Does Enhanced Photosynthesis Enhance Growth? Lessons Learned from $\mathrm{CO}_{2}$ Enrichment Studies. Plant Physiology, 155, 117-124. http://dx.doi.org/10.1104/pp.110.166819 
[10] Gaenszle, M., Bickel, B., Banjade, G., Lieven, E., Paudyal, N., Rai, I. and Stoll, S. (2005) Worshiping the King God: A Preliminary Analysis of Chintang Ritual Language in the Invocation of Rajdeu. Contemporary Issues in Nepalese Linguistics, 33-47.

[11] Shaw, K.P. (2014) Nepal Trek: A Woman Alone. BookWhirl Publishing, San Francisco.

[12] Erik Runkle, M.B. (2010) Ready Research Results: Daily Light Integral \& Flowering of Annuals. Greenhouse Growers, Willoughby.

[13] Loehrlein, M.M. and Craig, R. (2004) The Effect of Daily Light Integral on Floral Initiation of Pelargonium $\times$ domesticum LH Bailey. HortScience, 39, 529-532.

[14] Marcelis, L. (1996) Sink Strength as a Determinant of Dry Matter Partitioning in the Whole Plant. Journal of Experimental Botany, 47, 1281-1291. http://dx.doi.org/10.1093/jxb/47.Special Issue.1281

[15] Moccaldi, L.A. and Runkle, E.S. (2007) Modeling the Effects of Temperature and Photosynthetic Daily Light Integral on Growth and Flowering of Salvia splendens and Tagetes patula. Journal of the American Society for Horticultural Science, 132, 283-288.

[16] Blanchard, M. and Runkle, E.S. (2011) The Influence of Day and Night Temperature Fluctuations on Growth and Flowering of Annual Bedding Plants and Greenhouse Heating Cost Predictions. HortScience, 46, 599-603.

[17] Van Iersel, M. and Seymour, L. (2002) Temperature Effects on Photosynthesis, Growth Respiration, and Maintenance Respiration of Marigold. In: XXVI International Horticultural Congress: Elegant Science in Floriculture, 624, 549554.

[18] Shvarts, M., Weiss, D. and Borochov, A. (1997) Temperature Effects on Growth, Pigmentation and Post-Harvest Longevity of Petunia Flowers. Scientia Horticulturae, 69, 217-227. http://dx.doi.org/10.1016/S0304-4238(97)00015-0

[19] Gul, F. and Tahir, I. (2012) Effect of Dry and Wet Storage at Cool Temperatures on Postharvest Performance of Narcissus tazetta cv. Kashmir Local Flowers. Journal of Horticultural Science \& Ornamental Plants, 4, 75-83. 
Scientific Research Publishing (SCIRP) is one of the largest Open Access journal publishers. It is currently publishing more than 200 open access, online, peer-reviewed journals covering a wide range of academic disciplines. SCIRP serves the worldwide academic communities and contributes to the progress and application of science with its publication.

Other selected journals from SCIRP are listed as below. Submit your manuscript to us via either submit@scirp.org or Online Submission Portal.
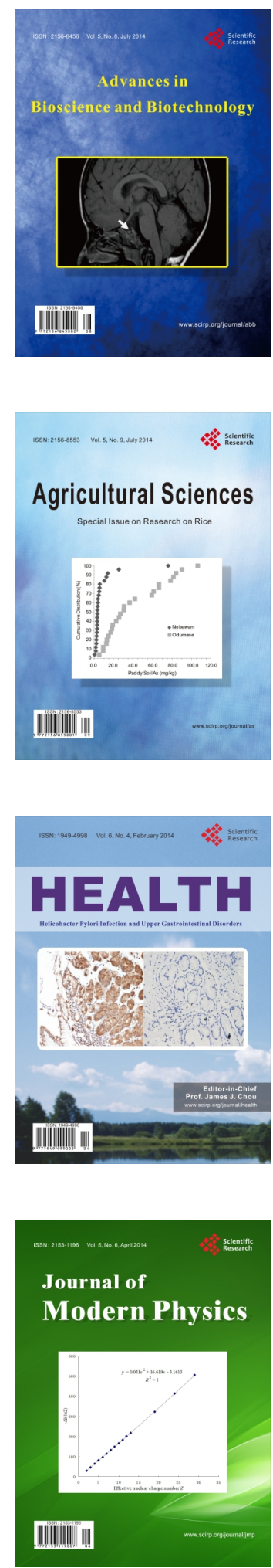
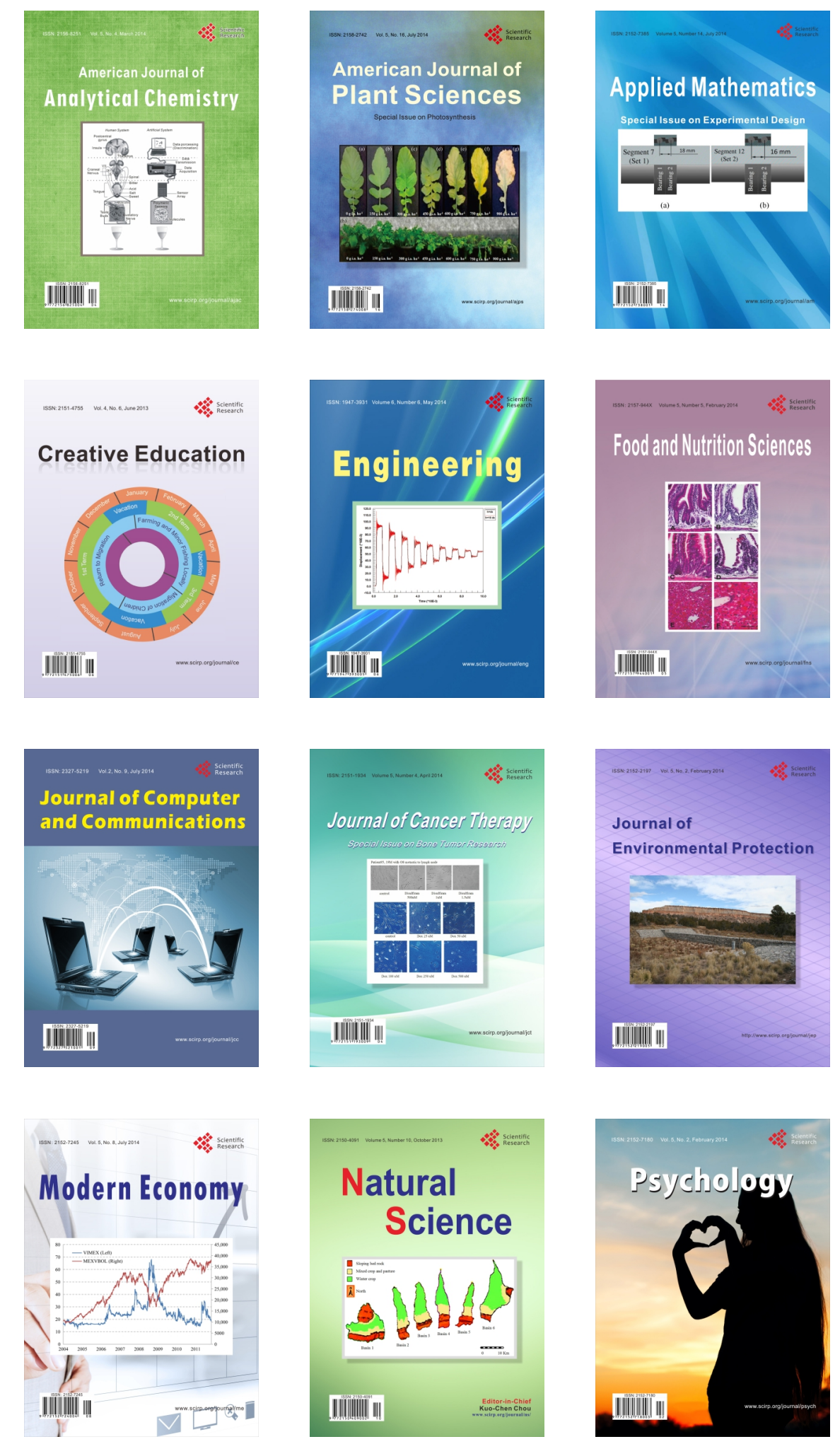